\title{
Amdinocillin Pivoxil
}

National Cancer Institute

\section{Source}

National Cancer Institute. Amdinocillin Pivoxil. NCI Thesaurus. Code C76216.

The pivoxil ester form of a semisynthetic, broad spectrum beta-lactam penicillin with antibacterial activity. Amdinocillin specifically binds to and inactivates penicillin-binding protein 2 (PBP 2) located on the inner membrane of the bacterial cell wall. Inactivation of PBPs interferes with the cross-linkage of peptidoglycan chains necessary for bacterial cell wall strength and rigidity. This interrupts bacterial cell wall synthesis and results in the weakening of the bacterial cell wall, eventually causing cell lysis. 